\title{
Sceptical Elements in a Dogmatic Stance: Isaac Polqar against Kabbalah
}

\section{Introduction}

As already announced elsewhere, I am going to publish a series of articles on the early opponents of Kabbalah focussing on sceptical elements and strategies. ${ }^{1}$ Jewish philosophers-especially those who were indebted, to one degree or another, to the philosophy of Aristotle as interpreted in the Middle Ages-presented a major field of opposition to Kabbalah. The fundamental arguments of any philosophical criticism of Kabbalah had already been provided by Maimonides, although it appears he barely knew anything of its esoteric lore. Menachem Kellner's monograph Maimonides' Confrontation with Mysticism is a very useful starting point for understanding why Maimonides is so vital to many opponents of Kabbalah. ${ }^{2}$ According to Kellner, Maimonides' philosophy can provide the blueprint for any philosophical criticism of mystical and kabbalistic claims. Kellner's 'proto-kabbalistic' examples of Maimonides' criticism encompass Heikhalot literature and the Sefer Yeșirah ('Book of Creation') as well as the Jewish magical tradition. ${ }^{3}$ It is well known that Maimonides' philosophy is deeply engaged with Aristotle as the latter was transmitted and revised in the Arabic tradition. The commentaries of Averroes, who was also known as Ibn Rushd (1126-1198), on various works of Aristotle are especially important for the later Jewish reception of Aristotelian philosophy within the tradition of Maimonidean philosophers. ${ }^{4}$

This article is a result of a long-term research project carried out at the Maimonides Centre for Advanced Studies at the University of Hamburg. I am indebted to my colleagues there and to our visiting fellows for presenting and discussing different aspects of Isaac Polqar at several Reading and Dialectical Evenings as well as for personal conversations I have had with them. I am especially grateful to Racheli Haliva, Lawrence Kaplan, Yuval Harari, and Elisa Carandina.

1 Bill Rebiger, "The Early Opponents of the Kabbalah and the Role of Sceptical Argumentations: An Outline," in Yearbook of the Maimonides Centre for Advanced Studies 2016, eds. Giuseppe Veltri and Bill Rebiger (Berlin and Boston: De Gruyter, 2016): 39-57.

2 Menachem Kellner, Maimonides' Confrontation with Mysticism (Oxford and Portland, OR: The Littman Library of Jewish Civilization, 2006).

3 Ibidem, $18-25$.

4 Cf., e. g., Alfred Ivry, "Remnants of Jewish Averroism in the Renaissance," in Jewish Thought in the Sixteenth Century, ed. Bernard D. Cooperman (Cambridge: Cambridge University Press, 1983): 243265; Steven Harvey, "Arabic into Hebrew: The Hebrew Translation Movement and the Influence of Averroes upon Medieval Jewish Thought," in The Cambridge Companion to Medieval Jewish Philosophy, eds. Daniel H. Frank and Oliver Leaman (Cambridge: Cambridge University Press, 2003): 268272.

Ә OpenAccess. (c) 2018 Bill Rebiger, published by De Gruyter. (cc) BY-NC-ND This work is licensed under the Creative Commons Attribution-NonCommercial-NoDerivatives 4.0 License. 
Regarding these preliminary considerations, it is not surprising that opposition to Kabbalah was to a large extent formed by philosophers who belong to the Aristotelian-Maimonidean tradition. In particular, several Jewish Averroists, among whom I would like to mention Jacob Anatoli, Isaac Albalag, Isaac Polqar, Moses Narboni, and Elijah Delmedigo, contributed polemics against Kabbalah in their works. In fact, the designation of 'Jewish Averroists' gathers together various distinctive philosophers who first and foremost share an interest in Averroes' works, particularly his commentaries on Aristotle. As a rule, this interest does not imply that every Averroist entirely agreed with Averroes and vice versa. ${ }^{5}$ Another distinguishing feature of Jewish Averroists is clearly outlined in their efforts to somehow combine Averroes' thought with that of Maimonides. The Averroistic precondition that a human being - provided he or she is a philosopher-may explain not only everything that exists, but also the underlying principle(s), leads to a general mistrust or even criticism of mystical and-in the Jewish context-kabbalistic interpretations. The knowledge for which the philosopher strives even includes knowledge of God or-at least from the Averroistic point of view-of the active intellect. This is indeed a dogmatic statement and apparently quite distant from any sceptical position regarding epistemology. However, despite the observation that many Jewish Averroists were non-sceptics, at least in their epistemological concepts, nonetheless certain sceptical elements or strategies can be detected in their works. It is the aim of my intended case studies to discuss certain sceptical elements and strategies implemented by the aforementioned Jewish Averroists.

The a priori of any polemic is the assumption that the adversary's knowledge is necessarily wrong and that his claims are to be refuted and disproved. Thus, the front line a polemic evokes must appear extremely clear-cut. In this regard, any statement intended for the purposes of polemics appears in no way akin to the sceptical approach. In contrast to sceptical enquiry, discussion, or open-ended disputewhich, to be more specific, may even be without any intention or purpose, following the tradition of Sextus Empiricus - the intention of polemics is at the very outset to affirm only the truth of one side, i.e. that of the polemicist. In this sense, criticism of Kabbalah, especially in the camp of Jewish Averroists, is very often non-sceptical or dogmatic insofar as the final truth of their philosophical claims of knowledge is obviously not in question.

What the rationalist philosophers actually criticise is Kabbalah's all-too-frequent absence of argumentation by reasoning according to philosophical principles. Or, to put it another way, the kabbalistic discourse was considered to be completely different to the philosophical one. Sceptical elements or strategies are especially fruitful when the participants of a debate do not share the same discourse or logic of argumentation and proofs, as is expressed in the Latin maxim contra principia negantem

5 Cf., e.g., Oliver Leaman, "Is Averroes an Averroist?," in Averroismus im Mittelalter und in der Renaissance, eds. Friedrich Niewöhner and Loris Sturlese (Zürich: Spur Verlag, 1994): 9-22. 
non est disputandum. Thus, the argumentation against certain content-related claims is less important than the attempt to undermine the certainty, authority, or legitimacy of a text, person, or institution as a source of knowledge. Therefore, the sceptical element found in many anti-kabbalistic texts is often expressed as doubt about authority and tradition as sources of knowledge, as will be discussed below. These sceptical elements could eventually be elaborated into sceptical strategies by later authors, such as, for instance, the Venetian Rabbi Simone Luzzatto (?1583-1663). ${ }^{6}$ When the rather simplistic doubting of authority and tradition termed here as only a 'sceptical element' is transformed into a subversive method for systematically undermining the reliability of sources of knowledge which are accepted only by authority or tradition, I would then like to call this a 'sceptical strategy.'

In the following, my aim is to present a case study devoted to the philosopher and polemicist Isaac Polqar (second half of the thirteenth century-c. 1330). The present article provides the reader with the first translation of a passage dealing with his attack on kabbalists into a modern language and a commentary on it through a close reading focussing on the sceptical elements to be detected therein.

\section{Isaac Polqar}

Isaac ben Joseph ibn Polqar ${ }^{7}$ lived in Christian Spain, or more precisely, in the Kingdom of Castile. Not much of his biography is known to us. Polqar was clearly a philosopher in the tradition of Maimonides, Averroes, and Isaac Albalag. ${ }^{8}$ According to a poem dedicated to him by Samuel ibn Sasson, Polqar was an expert in the study of

\footnotetext{
6 On my definition of sceptical strategies such as relativisation, objectification, historicisation, indictment of heresy, and delegitimation, see Bill Rebiger, "Sceptical Strategies in Simone Luzzatto's Presentation of the Kabbalists in his Discorso," in Yearbook of the Maimonides Centre for Advanced Studies 2017, ed. Bill Rebiger (Berlin and Boston: De Gruyter, 2017): 53-64.

7 Variants of the correct spelling of Polqar, such as Policar, Pollegar, Polgar, or Pulgar, can be found elsewhere.

8 On Polqar, cf., e.g., Racheli Halevi, Isaac Polqar-A Jewish Philosopher or a Philosopher and a Jew? A Study of the Relationship between Philosophy and Religion in Isaac Polqar's 'Ezer ha-Dat [In Support of the Religion] and Teshuvat Apikoros [A Response to the Heretic] (typescript, PhD McGill Montreal, 2015; Berlin and Boston: De Gruyter, forthcoming); Shalom Sadik, "La différence entre judaïsme et christianisme selon deux averroïstes juifs espagnols," Viator 47 (2016): 191-204; idem, "Negation of Political Success in the Thought of Rabbi Isaac Pulgar," AJS Review 39 (2015): 1-13 (Hebrew section); Shlomo Pines, "Spinoza's Tractatus Theologico-Politicus and the Jewish Philosophical Tradition," in Jewish Thought in the Seventeenth Century, eds. Isadore Twersky and Bernard Septimus (Cambridge, MA: Harvard University Press, 1987): 499-521; idem, "Some Topics on Polqar's Treatise 'Ezer ha-Dat and their Parallels in Spinoza's View," in Studies in Jewish Mysticism, Philosophy and Ethical Literature, Presented to Isaiah Tishby on his Seventy-Five Birthday, eds. Joseph Dan and Joseph Hacker [in Hebrew] (Jerusalem: Magnes Press, 1986): 395 - 457; Colette Sirat, A History of Jewish Philosophy in the Middle Ages (Cambridge: Cambridge University Press, 1985): 315-322; Isidore Loeb, "Polémistes Chrétiens et Juifs en France et en Espagne,” Revue des études juives 18 (1889): 63-70.
} 
the Hebrew Bible and the Mishnah. He was also known as a poet and physician and was an acknowledged authority in his congregation. ${ }^{9}$ However, Polqar is first and foremost known as the student of the Jewish scholar Abner of Burgos, whom he admired as his beloved master. Abner lived between 1265 and 1347 and eventually converted to Christianity between 1320 and 1322. After his conversion, he adopted the Christian name Alfonso of Valladolid and began writing anti-Jewish polemics in Hebrew. ${ }^{10}$ Abner's conversion was an essential event for Polqar and one that caused him to question his Jewish self-confidence. As a result, he began to compose his own polemics against Christianity in general and against Abner in particular.

Most of Polqar's books have not survived. Among his lost works, he reportedly wrote commentaries on the biblical books of Genesis, Ecclesiastes, and the Psalms. Nevertheless, only two of Polqar's works exist today. The first is a letter addressed to Abner known by the title Teshuvat Apikoros ('A Response to the Heretic'). ${ }^{11}$ Unfortunately, this is the only surviving text of a far larger correspondence between Polqar and Abner. The second of Polqar's works to have survived is his magnum opus 'Ezer ha-Dat ('In Support of the Religion'). I will proceed by presenting the chapter of this book that contains Polqar's attack on the kabbalists and discussing it at length. In addition, one of his lost writings, a book entitled Musar ha-Banim ('Instruction of the Sons'), is mentioned in the passage translated below.

In his writings, Polqar attempted to defend the Jewish faith not only against Christians by birth, but also against Jewish converts, particularly those well trained in biblical and talmudic sources. Polqar was a fiery adept of Aristotelian philosophy and Averroes' commentaries on Aristotle's works. In Polqar's view, Judaism is a true religion because its beliefs are possible according to their philosophical principles. ${ }^{12}$ Therefore, Judaism is superior to Christianity and its theological concepts of the Trinity and the Incarnation are beliefs which Polqar deems and dismisses as logically impossible. ${ }^{13}$ Another target of his polemics takes on other philosophical schools as

9 Cf. Yitzhak Baer, "Fragments from Castilian Poets in the Fourteenth Century," in Minhah le-David: Collected Studies on Jewish Wisdom Presented to David Yellin for his Seventieth Birthday [in Hebrew], ed. Jubilee Committee (Jerusalem: Ruben Mass, 1935): 200.

10 On Abner, see Jonathan L. Hecht, The Polemical Exchange between Isaac Pollegar and Abner of Burgos/Alfonso of Valladolid according to Parma MS 2440 (PhD Diss., New York University, 1993); Ryan Szpiech, From Testimonia to Testimony: Thirteenth-Century Anti-Jewish Polemic and the Mostrador de justicia of Abner of Burgos/Alfonso de Valladolid (PhD Diss., Yale University, New Haven, CT, 2006); Shalom Sadik, "Abner de Burgos and the Transfer of Philosophical Knowledge between Judaism and Christianity," Medieval Encounters 22 (2016): 95-112.

11 The only manuscript evidence is Ms Parma, Pal. 2440, where no title for this letter is given; see Hecht, Polemical Exchange. However, the title Teshuvat Apikoros is referred to by Isaac Polgar, Ezer HaDat. A Defense of Judaism [in Hebrew], ed. Jacob S. Levinger (Tel Aviv: The Chaim Rosenberg School of Jewish Studies, 1984), 30 and 76.

12 Cf. Polgar, Ezer HaDat, ed. Levinger, 34-40.

13 On the distinction between possible and impossible religious beliefs according to Maimonides, cf. Daniel J. Lasker, Jewish Philosophical Polemics Against Christianity in the Middle Ages (Oxford and Portland, Oregon: The Littman Library of Jewish Civilization, 2007), 28-43. 
well as astrologers and kabbalists. Polqar attacked the latter as they argued against the philosophical interpretation of the Jewish religion, particularly in its Aristotelian-Averroistic form. A further reason to attack Kabbalah lay in the probability that Abner had implemented kabbalistic ideas to support himself in his conversion. ${ }^{14}$

\section{Polqar against the Kabbalists in his 'Ezer ha-Dat ('In Support of the Religion')}

In literary terms, 'Ezer ha-Dat is made up of dialogues and essays. The first and fourth chapters are written as essays, while the second, third, and fifth chapters are composed in dialogue form. I would like to emphasise that already in the last dialogue of the second chapter between the old traditionalist and the young philosopher about the limits of human knowledge and the exalted rank of the prophets, the traditionalist mentions various secrets including, among others, divine names, the kabbalistic concept of the ten Sefirot, and the Sefer Yeșirah. ${ }^{15}$ According to the traditionalist, who evidently became a kabbalist during his life, the prophets transmitted these secrets to him via the chain of tradition.

However, the polemic against the kabbalists presented below can be found in the fourth chapter in which he attacks four different groups, accusing all of them of being Judaism's greatest enemies. Among these are the self-proclaimed true believers who reject science, the kabbalists, the philosophers who hold radical naturalistic views, and lastly adepts of magic and superstition. According to Polqar, the kabbalists are dangerous because they assert that they have knowledge that does not follow Aristotle's philosophical methods and logical rules. ${ }^{16}$ In contrast, the knowledge that the kabbalists claim to have is provided by an esoteric tradition reaching back to the time of the prophets, as they claim.

The Hebrew word 'Kabbalah' literally means 'tradition.' Both philosophy and Kabbalah express truth claims with regard to the interpretation of texts. They both agree that truth is mostly hidden and not obvious in the texts, or that truth is nothing but the deeper meaning behind the surface of the literal sense. Thus, kabbalists frequently qualify their interpretations of the Torah, for instance, as being found 'by the

14 Cf. Yitzhak Baer, "The Use of Kabbalah in the Christological Thought of Abner of Burgos," Tarbiz 16 (1909): 280 - 289; Shoshana Gershenzon, A Study of Teshuvot La-Meharef by Abner of Burgos (PhD Diss., Jewish Theological Seminary of America, 1984); but see the critique by Shalom Sadik, Trinity and Determinism in the Thought of Abner of Burgos (PhD Diss., Ben-Gurion University of the Negev, 2011).

15 See Polgar, Ezer HaDat, ed. Levinger, 84-87; however, the term 'Kabbalah' is not explicitly mentioned here.

16 Cf. the short summary in Carlos del Valle, "La critique de la Qabbale chez Isaac ibn Polgar," in Expérience et écriture mystique dans les religions du livre, eds. Paul B. Fenton and Roland Goetschel (Leiden: Brill, 2000): 131-141. 
way of truth' ('al derekh ha-'emet in Hebrew). Among many Jewish scholars of Polqar's time, Kabbalah was firstly a 'generally accepted opinion' and secondly acknowledged as a tradition received by trustworthy persons. According to Maimonides' Treatise on the Art of Logic, ${ }^{17}$ these two sources of kabbalistic knowledgemore precisely, generally accepted opinions and traditions-are not self-evident because they depend solely on the social environment and testimony. Therefore, Kabbalah cannot be accepted as a source of knowledge whose conclusions are already certain from the outset. However, the majority of kabbalists would not accept this kind of epistemological argument simply by dint of the fact that they do not agree with Aristotelian standards of philosophy and logic. Furthermore, content-related attempts to falsify kabbalistic ideas would not be accepted because of the pluralistic hermeneutics concerning truth claims shared by most kabbalists. Therefore, another, more subversive way to undermine the meta-level or frame of the kabbalistic selfimage appears to be more effective. Thus, the assertion that Kabbalah is indeed an ancient tradition, as the literal meaning of the term suggests, was something that Polqar particularly doubted, and a sceptical element can be seen in Polqar's attempt to undermine the acceptance of his contemporaries' kabbalistic opinions when he claims Kabbalah is neither an ancient tradition nor a real one. In this way, he attempts to undermine the reliability of kabbalistic genealogy and authorities. Polqar's main sceptical element is to assert doubts concerning the textual accuracy of kabbalistic sources. He deconstructs Kabbalah's presentation of itself as a reliable tradition continuously transmitted since antiquity. However, Polqar's dogmatic stance concerning Kabbalah is evident throughout this passage. In general, he has no doubt that Kabbalah cannot be accepted because of its non-philosophical means of arguing. On several occasions, he goes so far as to explicitly debunk Kabbalah as 'foolishness' and castigates kabbalists as 'ignorants.'

What follows is a complete English translation of the passage from 'Ezer ha-Dat in which Polqar attacks the kabbalists. The translation is based on the Jacob S. Levinger edition of the original Hebrew text. ${ }^{18}$ The passage has been divided into smaller portions to enable me to comment on them directly in the close reading. The Hebrew original of the quoted passages is given in the footnotes according to Levinger's edition.

17 Cf. Hannah Kasher, "Maimonides: Halakhic Philosopher or Philosophical Halakhist? On Skeptical Epistemology and Its Implications," in Moses Maimonides (1138-1204): His Religious, Scientific, and Philosophical Wirkungsgeschichte in Different Cultural Contexts, eds. Görge K. Hasselhoff and Otfried Fraisse (Würzburg: Ergon 2004): 51-63.

18 Polgar, Ezer HaDat, ed. Levinger, 156-158. 


\section{Translation and Commentary}

After his attack on Jews defining themselves as true believers while actually rejecting science, Polqar commences his polemic against the second group, the kabbalists, with the following lines:

And the second objection is the objection of the group of people who are called 'kabbalists' [mequbbalim] in this generation. And these are those who say that since man's intellect is unable to apprehend anything hidden through his contemplation, that is to say, by seeking a conclusion from known premises, the only way is that of a Kabbalah ['tradition'] that was taken from a prophet. And (they furthermore say) that they know and recognise in truth that the Kabbalah that today is in their possession is the one which was heard from the mouths of the prophets. ${ }^{19}$

The second group Polqar attacks consists of "people who are called "kabbalists" in this generation.' In the beginning, Polqar already emphasises that they are merely called 'kabbalists,' that is, 'receivers of a tradition,' but they are not even such receivers in his view. In this passage, Polqar tries to argue precisely both that the kabbalists are not reliable receivers of the tradition and that the kabbalistic tradition itself is not reliable. However, the kabbalists were obviously a distinctive group in the first half of the fourteenth century. Christian Spain, where Polqar resided, was one of the most important sites of kabbalistic writing in Polqar's period, as it had been in the previous century. Major works of the kabbalistic tradition, such as the Sefer ha-Bahir, most of the texts later compiled in the Sefer ha-Zohar, and kabbalistic commentaries on the Hebrew Bible or the Sefer Yeșirah, had already been written and disseminated. Crucial authors of various kabbalistic trends such as Isaac the Blind (c. 11601235), Azriel of Gerona (c. 1160-c. 1238), Moses Nahmanides (1194-1270), Menahem Recanati (1223-1290), Moses de Leon (c. 1240 -1305), Abraham Abulafia (1240-after 1291), Joseph Gikatilla (1248-after 1305), or Isaac of Acre (thirteenth to fourteenth century) had been active long before Polqar arrived on the scene. Nevertheless, Kabbalah was still a set of various lores studied first and foremost by the Jewish elite. ${ }^{20}$ However, magical practices were much more popular among less educated people, and in this period they begin to intermingle with kabbalistic ideas. ${ }^{21}$ The results of

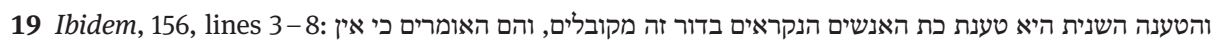

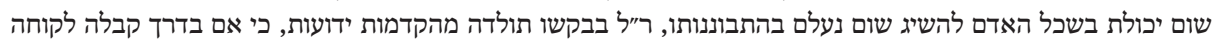

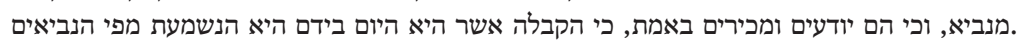

20 For surveys on the early history of Kabbalah, cf., e.g., Gershom Scholem, Origins of the Kabbalah, trans. Allan Arkush (Philadelphia: Jewish Publication Society and Princeton University Press, 1990); Joseph Dan, The Early Kabbalah (New York: Paulist Press, 1986); Hava Tirosh-Samuelson, "Philosophy and Kabbalah: 1200-1600," in The Cambridge Companion to Medieval Jewish Philosophy, eds. Daniel H. Frank and Oliver Leaman (Cambridge: Cambridge University Press, 2003): 218-257; Jonathan Dauber, Knowledge of God and the Development of Early Kabbalah (Leiden and Boston: Brill, 2012).

21 On mediaeval Jewish magic, cf. Joshua Trachtenberg, Jewish Magic and Superstition. A Study in Folk Religion (New York: Behrman's Jewish Book House, 1939; reprinted Philadelphia: University of 
this process were eventually dubbed 'practical Kabbalah' and, as we will see later, they became of some relevance for Polqar. ${ }^{22}$

Polqar introduces the kabbalists in a very significant way: surprisingly, he does not focus on kabbalistic ideas, but rather on the epistemological difference between kabbalistic and philosophical approaches for obtaining true and certain knowledge. In Polqar's philosophy, men gain truth with the assistance of the rational speculation of the intellectual faculty. Using the intellectual faculty, the philosopher is also able to apprehend hidden things by means of Aristotelian reasoning and to draw a conclusion from known premises. By contrast, the kabbalist denies this ability of the philosopher in particular and human beings in general by means of a virtually sceptical approach. Instead, the kabbalist prefers to rely on a tradition that goes back to the prophets when it comes to hidden truths. Therefore, in an anonymous text entitled 'Chapter on the kawwanah, by the ancient kabbalists,' for instance, which according to Gershom Scholem was probably written by the early kabbalist Azriel of Gerona, the following identification with prophecy is included at the end of a passage dealing with the kabbalistic concept of kawwanah or the required intention or devotion while praying or fulfilling the commandments:

And this [i.e. kawwanah] is the path among the paths of prophecy, upon which he who makes himself familiar with it will be capable of rising to the rank of prophecy. ${ }^{23}$

However, the most important example of a prophetic interpretation of Kabbalah is provided by Abraham Abulafia, who claimed to be a prophet, a mystic, and the messiah all at once. ${ }^{24}$ In Polqar's view, prophecy has nothing to do with true knowledge, since it is nothing but imagination. ${ }^{25}$ Maimonides argues that every prophet is nec-

Pennsylvania Press, 2004); Yuval Harari, Jewish Magic before the Rise of Kabbalah (Detroit: Wayne State University Press, 2017).

22 On practical Kabbalah, cf. Gershom Scholem, Kabbalah (Jerusalem: Keter, 1988): 182-189; Moshe Idel, "Defining Kabbalah: The Kabbalah of the Divine Names," in Mystics of the Book: Themes, Topics, and Typologies, ed. Robert A. Herrera (New York: Peter Lang, 1993): 97-122; idem, "On the Theologization of Kabbalah in Modern Scholarship," in Religious Apologetics-Philosophical Argumentation, eds. Yossef Schwartz and Volkhard Krech (Tübingen: Mohr Siebeck, 2004): 142-145.

23 See Scholem, Origins of the Kabbalah, 419. On the view of another late thirteenth-century kabbalist, Rabbi Joseph ben Shalom Ashkenazi, concerning the visualisation of letters and colours as a technique for achieving the prophetic state, cf. Moshe Idel, Kabbalah: New Perspectives (New Haven and London: Yale University Press, 1988), 105-106.

24 On Abraham Abulafia, cf. the many books and articles written by Moshe Idel, e. g., idem, The Mystical Experience in Abraham Abulafia (Albany: SUNY Press, 1987); idem, Studies in Ecstatic Kabbalah (Albany: SUNY Press, 1988); idem, Language, Torah, and Hermeneutics in Abraham Abulafia (Albany: SUNY Press, 1989).

25 On Polqar's inventive view of prophecy and the prophet's knowledge being differentiated from the philosopher's knowledge, see also Polgar, Ezer HaDat, ed. Levinger, 88-89 and 116-118; cf. Pines, "Some Topics on Polqar's Treatise 'Ezer ha-Dat and their Parallels in Spinoza's View," 420 -432; idem, "Spinoza's Tractatus Theologico-Politicus and the Jewish Philosophical Tradition," 501-503; 
essarily a philosopher and that a prophet is provided with both a perfect imaginative faculty and a perfect rational one. ${ }^{26}$ In contrast, Polqar clearly differentiates between the prophet and the philosopher. He maintains that although only Moses was both a perfect philosopher and a perfect prophet, all the other prophets are not philosophers because they use only imagination and intuition. In line with this, Polqar acknowledges the kabbalists insofar as they are similar to traditionalist Jews, for both maintain that the only source of true knowledge is tradition that goes back to the prophets. Both reject the philosophers by dint of the alleged limitations of man's intellectual faculty. ${ }^{27}$ In this epistemological regard, both the kabbalist and the traditionalist are sceptics. However, Polqar too is a sceptic insofar as he continues to question the kabbalists on the certainty of their own claims regarding the sources of knowledge that they use:

But if one will say to them [i.e. the kabbalists]: 'Whence do you know this?' or 'How is it that you do not take note and raise doubts (about your claim) and admit that it would be possible that these views (of the kabbalists) are not those that were heard from the mouths of the prophets? For (the views of the prophets) were forgotten and lost in the course of time in the crisis of changes, and in the troubles of sufferings which happened to our congregation due to our sins. ${ }^{28}$

One major characteristic of the philosophical approach in general and the sceptical approach in particular is to question one's own claims and enquire into their certainty. Obviously, this approach differs from the kabbalistic one, which accepts claims simply by following the tradition provided by the chain of genealogy and filiation from master to student without any opportunity to doubt. The problem, Polqar states, is the fact that prophecy already came to an end in biblical times. The historical explanation for the end of prophecy he gives is also intriguing. Israel's sins are the reason for the end of prophecy and the loss of the prophets' knowledge. The long period between the end of prophecy and the Kabbalah of his contemporaries is what Polqar's mistrust is founded upon. How can one rely with certainty on a tradition claiming to be that ancient? According to Polqar, the kabbalists would equate this situation with the reliability of the Torah and the writings of the prophets:

They [i.e. the kabbalists] will reply and say: 'Far be it from us that we should cast any doubt on those of our beliefs which were received [ha-mequbbalot] by us from the mouths of the people

Dov Schwartz, "Prophecy according to Isaac Polqar, Rabbi Shlomo Al-Konstantin, and Spinoza" [in Hebrew], Asufot 4 (1990): 60 -61; Shalom Sadik, Trinity and Determinism in the Thought of Abner of Burgos, 93-98; Haliva, Isaac Polqar, 251-268.

26 See Maimonides, Guide of the Perplexed, II:35-38 and II:45.

27 Polqar already ascribes this view to the traditionalist in the last dialogue of the second chapter, but without mentioning the kabbalist; see Polgar, Ezer HaDat, ed. Levinger, 84-87.

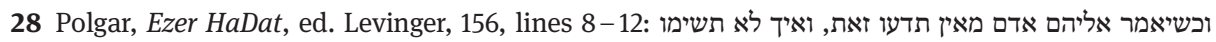
לבכם להסתפק ולומר כי איפשר שלא היו דעות אלה הם הנשמעים מפי הנביאים, כי היו נשכחים ונעדרים באורך הזמנים,

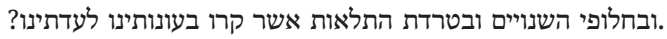


who are approved in our eyes, just as we do not doubt either the book of our Torah or the writings of our prophets, peace be upon them.' And they are so brazen as to compare and equate the stories of their foolishness to the Holy Scriptures. ${ }^{29}$

Regarding the kabbalists' equation of Kabbalah with Torah, any general doubt regarding the reliability of all these ancient texts would be inappropriate. This evokes a subtle dilemma for Polqar as he must avoid any conflict concerning the acceptance of the Torah as a source of knowledge while trying to argue against Kabbalah. At first, Polqar clearly states, in a very dogmatic way, that the equation of Kabbalah with Torah is brazen because the kabbalistic stories are to be considered nothing but foolishness. In mentioning 'stories,' Polqar is most likely alluding to kabbalistic Midrashim to be found, for instance, in the Sefer ha-Zohar. ${ }^{30}$ However, Polqar has to differentiate between the characteristics of Kabbalah and Torah. Thus, he presents two rather odd examples for the purpose of degrading Kabbalah as an allegedly ancient tradition. The first reads as follows:

\begin{abstract}
And they (obviously) do not know that from the day of the death of Moses, our master, all the people of our nation made constant efforts, were diligent and occupied themselves with preserving the traditional text of their writings, so that no (single) letter of them would be missed or others would be added. And all of them stated their intention to bequeath their children firm and wise ${ }^{31}$ books copied and checked from one another until today. But despite all their diligence and their efforts in (preserving) their traditional text, today there are to be found variants in the Holy Scriptures in several places. And this is known to anyone who examines the book of the Torah, which is well known among us as being in the handwriting of Ezra the priest, for there are to be found in it words that differ from similar (words) in the other checked books which are in our possession. ${ }^{32}$
\end{abstract}

In his first example, Polqar compares the transmission of the Holy Scriptures and kabbalistic sources. The argument ad antiquitatem (appeal to antiquity or tradition) provides the general background: a source is deemed correct on the basis that it is correlated with some past or present tradition. The widely accepted idea is that the antiquity of the source guarantees the truth of its text. In this case, Polqar adopts

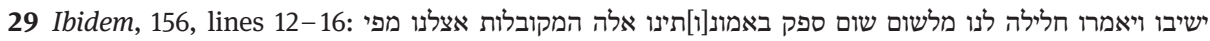

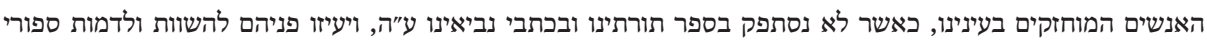
הבליהם לספרי הקדשת ספורי להפות.

30 Cf. Oded Yisraeli, Temple Portals: Studies in Aggadah and Midrash in the Zohar (Berlin and Boston: De Gruyter, 2016).

31 The Hebrew nevonim edited here by Levinger should probably be corrected to nekhonim, 'correct.'

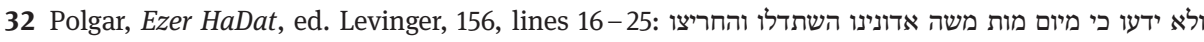

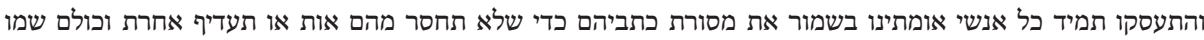

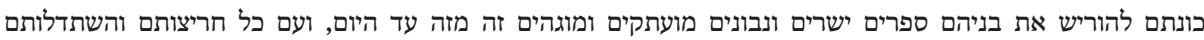

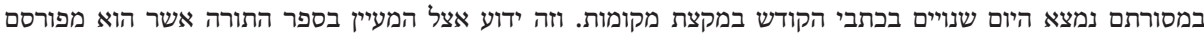

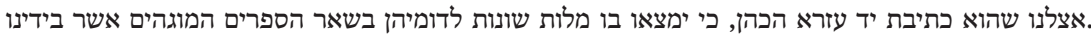


the traditional view that the Torah was revealed to Moses and put into writing by Ezra the priest, who was also called the scribe. ${ }^{33}$

However, Polqar's implicit premise states the fundamental difference between both literary traditions concerning the quality and accuracy of the textual transmission. Beginning already in rabbinic literature, evidence of textual variants and emendations in the circulating copies of the Hebrew Bible was discussed and guidelines for accurate copying were introduced. ${ }^{34}$ In the history of textual criticism, Christian authors such as Origen of Alexandria (c. 184-c. 253) and Jerome (347-420) or Jewish authors such as Abraham ibn Ezra (1089-c. 1167) and David Kimhi (1160 - 1235) were early forerunners who were aware of textual variants and related problems in the transmission of the Bible.

Polqar seems to accept, at least for a moment, that Kabbalah could indeed rely on ancient sources, only for the purpose of his argumentation. Hence, he aims to imply a so-called qal wa-homer conclusion or an argumentum a fortiori: if there are variants in even the Holy Scriptures despite the efforts made in copying and checking them, then the kabbalistic sources must be all the more deficient and therefore full of (scribal) errors and simply unreliable. But the implicit opposite case would probably be even more subversive: should there be no textual variants in a specific kabbalistic source of purported old age, such an absence of variants would prove that the source was not an ancient one.

Polqar's implicit sceptical argument of doubting the textual accuracy of kabbalistic sources concerning their transmission since antiquity deconstructs Kabbalah's presentation of itself as an ancient tradition. Later, in the seventeenth century, this argument was elaborated into the philological method of textual criticism (e.g. Jean Morin and Richard Simon) and eventually into a general scepticism concerning ancient sources and the Holy Scriptures. However, in my view, Polqar did not intend this kind of general sceptical strategy regarding textual reliability. In addition, I would like to emphasise that in Polqar's view, Kabbalah is understood first and foremost as a written text based on ancient written sources. This may apply for kabbalistic works as the Sefer ha-Bahir attributed to Rabbi Nehuniah ben ha-Qanah or the Sefer ha-Zohar attributed to Rabbi Shim on bar Yohai. However, he does not consider either the possibility of an oral transmission of kabbalistic lores via filiation from master to student from ancient times or the recent or contemporary production of kabbalistic texts in his time.

In the following, Polqar describes the peculiarities of kabbalistic writings:

And when a man reads the books found among these kabbalists, he will find their words in two ways:

33 Cf. Ezra 7:6; 2 Esdras 14:44-46; Babylonian Talmud, Sanhedrin 21b.

34 Cf. Saul Lieberman, Hellenism in Jewish Palestine (New York: The Jewish Theological Seminary of America, 1994), 20 -37; Emanuel Tov, Textual Criticism of the Hebrew Bible (Minneapolis: Fortress Press, 2001). 
The first is strange words (which) frighten the listener (but) without signifying any matter of internal logic, and they are only babbling of the lips. And (the) wickedness of their hearts and (the) strength of their stupidity cause them to justify and believe in a matter before its perception, something which it is forbidden (to do) according to the art of logic. For they know not, neither will they understand; they walk on in darkness [Psalm 82:5].

And the second is that the majority of things (they write) which are possible for man to contemplate on any matter by internal logic will be found to be the opposite of what the intellect and the judgment ${ }^{35}$ would approve. And others of them are complete heresy due to the contradiction of the unity of God, blessed be He, and a denial of His real attributes. ${ }^{36}$

As in the previous example, Polqar does not refer to the essentials of the (theosophical) Kabbalah such as the concept of the Sefirot or the theurgical interpretation of the commandments. Instead, he focusses on the meaning of logic and intellectual approaches from a philosophical or epistemological perspective. First, the aforementioned 'strange words' are a literal translation of the Latin technical term nomina barbara, known as the divine, angelic, or demonic magical names used in adjurations. These names-usually without a semantic meaning in the language of the magical text and its users-are nevertheless acknowledged by magicians and clients as the agents of magical efficacy. ${ }^{37}$ As these names are often used in maleficent magic, they are frightening for the reader. A broader interpretation of those 'strange words' emphasises the lack of internal logic and argument. Therefore, they are nothing but nonsense or 'babbling of the lips.' Again, Polqar dogmatically adjudges the kabbalists as wicked and stupid.

Secondly, according to Polqar, kabbalistic texts contradict logical principles in most cases. Incidentally, the Hebrew phrase for 'judgment' that Polqar uses is shiqqul ha-da'at or 'balancing of the mind.' Perhaps this phrase somehow recalls the sceptical ability to balance out the persuasive force of arguments for and against any disputed claim (equipollence). Furthermore, Polqar asserts Kabbalah to be not only nonlogical, but also heretical. Indictment of heresy is often used in polemics. ${ }^{38}$ At the end of the quoted passage, Polqar is very probably alluding to the kabbalistic concept of the ten Sefirot when he writes: 'Others of them are complete heresy due to

35 Literally 'the balancing of the mind' or 'common sense.'

36 Polgar, Ezer HaDat, ed. Levinger, 156, line 25 to 157, line 6: וכשיקרא האדם בספרים הנמצאים מהמקובלים

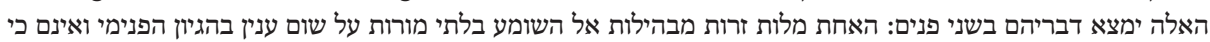

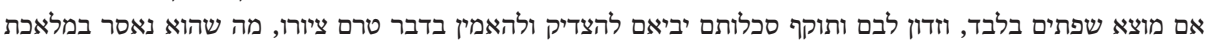

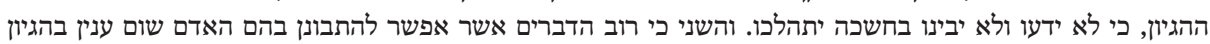

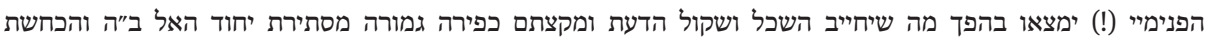

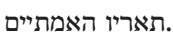

37 On nomina barbara and the use of magical names in Jewish magic, cf. Trachtenberg, Jewish Magic and Superstition, 78-103; Idel, Language, Torah, and Hermeneutics in Abraham Abulafia, 82-124; Daniel Abrams, "From Germany to Spain: Numerology as a Mystical Technique," Journal of Jewish Studies 47 (1996): 43-63.

38 On indictment of heresy as a sceptical strategy, cf. Rebiger, "Sceptical Strategies in Simone Luzzatto's Presentation of the Kabbalists in his Discorso," 63-64. 
the contradiction of the unity of God, blessed be He, and a denial of His real attributes.' The concept of the ten Sefirot contradicting the unity of God and, in doing so, the core concept of a monotheistic religion, is one of the major arguments levelled by the Jewish opponents of Kabbalah. Thus, it is no coincidence that many anti-kabbalistic criticisms are embedded in the context of anti-Christian polemics against the concept of the Trinity. Accordingly, circa 1230 - 1235, Meir ben Simon ha-Me'ili of Narbonne, most probably the first known opponent of Kabbalah, wrote about the kabbalists in his anti-Christian polemical work Milhemet Mișwah ('War by Commandment') in a passage comparing the concept of the Trinity with that of the Sefirot: 'Do there exist in our time, even among the religions of the gentiles, deniers ${ }^{39}$ of the unity of God, blessed be He, more (worthless) than these [i.e. kabbalists]?'40 Some decades later, circa 1280, the ecstatic kabbalist Abraham Abulafia further elaborated this line of argument in an epistle to his disciple entitled Ve-Zot le-Yehudah. In his letter, Abulafia sharply criticised the even worse case of the concept of the ten Sefirot in the theosophic Kabbalah. ${ }^{41}$

The next lines of Polqar's attack on the second group deal with the opposition between kabbalists and philosophers:

And those kabbalists to whom I speak are so brazen as to raise their voices to mock and despise those who make efforts to read the books of philosophy. And they say to them [i.e. the philosophers]: 'Why do you waste your days in studying these books of foolishness, since man's intellect is unable to attain hidden (matters), to perform miracles, and to change their nature?' And they [i.e. the kabbalists] are so presumptuous in themselves as (to claim that) they attain these matters without any effort and labour, but only by copying those books which are venerated in

39 Here I follow the conjecture of ספרים ('books') to כופרים suggested by Alon Goshen-Gottstein; cf. idem, "The Triune and the Decaune God: Christianity and Kabbalah as Objects of Jewish Polemics with Special Reference to Meir ben Simeon of Narbonne's Milhemet Mitzva," in Religious Polemics in Context, eds. Theo L. Hettema and Arie van der Kooij (Assen: Royal Van Gorcum, 2004): 190 n. 76. 40 The Hebrew text is found in the only manuscript attesting Milhemet Mișwah-that is, the Sephardic manuscript written around 1300, MS Parma 2749 (De Rossi 155), fol. 231b-and was published in a slightly abridged form by Gershom Scholem, "Te'udah hadašah le-rešit ha-qabbalah” [Hebrew], in Sefer Bialik, ed. Ya'akov Fikhman (Tel Aviv: Hoșa’at va’ad ha-yovel uve-hishtatfut hoșa'at omanut, 1934): $146-149$, reprinted in Gershom Scholem, Studies in Kabbalah, ed. Yosef ben Shelomo, vol. 1 (Tel Aviv: 'Am 'Oved, 1998), 7-38; cf. the English translation of the whole passage in idem, Origins of the Kabbalah, 398-400; cf. furthermore Heinrich Gross, "Meïr b. Simon und seine Schrift Milchemeth Mizwa," Monatsschrift für Geschichte und Wissenschaft des Judentums 30 (1881): 295 - 305, 444452 and 554-569; Adolf Neubauer, “The Bahir and the Zohar,” Jewish Quarterly Review 4 (1892): 357360.

41 Abraham Abulafia, Sefer Razei Hayyei 'Olam ha-Ba (Jerusalem: Amnon Gross, 1999), 22 ff.; cf. Moshe Idel, Kabbalah: New Perspectives, xii; idem, Studies in Ecstatic Kabbalah, 139; Elliot R. Wolfson, "The Doctrine of Sefirot in the Prophetic Kabbalah of Abraham Abulafia," Jewish Studies Quarterly 2.4 (1995): 341-343. 
their eyes (and) which were concealed and hidden in the houses of the glorious sages until God delivered their being copied into their hands. ${ }^{42}$

In this passage, Polqar reflects the frontline between kabbalists and philosophers mockingly calling one another as foolish and non-effective. When the kabbalist claims that the philosopher is not able to attain hidden matters, to perform miracles, or to change nature, according to Polqar he implicitly states that he himself is able to do so. All three abilities define the specific features of a biblical prophet. In contrast, a philosopher such as Polqar cannot understand how one could claim such an ability without any intellectual effort but relying only on transmitted texts. Here, the textual criticism concerning the accuracy and reliability of the transmission of kabbalistic texts already implicitly presented in the previous section leads to the final subversive goal of his argument, which is specifically the complete neglect of that which is essential to Kabbalah according to its abovementioned literal meaning, i.e. its claim of being a reliable tradition.

The sentence about the books 'which were concealed and hidden in the houses of the glorious sages' probably alludes to the pseudepigraphical attribution of the Sefer ha-Zohar to Rabbi Shim on bar Yohai, who lived in the second century, and to the thirteenth-century kabbalists' explanation as to why this and similar texts had only appeared now after centuries of being hidden. So, for example, Moses de Leon, who was, at least to a certain degree, engaged in the production of zoharic literature, writes in his Sefer Mishkan ha- ${ }^{\circ} d u t:$

Concerning this matter, there are hidden mysteries and secret things which are unknown to men. You will now see that I am revealing deep and secret mysteries which the holy sages regarded as sacred and hidden, profound matters which properly speaking are not fit for revelation so that they may not become a target for the wit of every idle person. [...] And they [the sages] have closed and locked the door behind their words and hidden all their mystical books, because they saw that the time had not come to reveal and publish them. ${ }^{43}$

In his second example, Polqar presents Kabbalah as first and foremost being practical Kabbalah, although in this case it is actually non-kabbalistic magic. In Polqar's

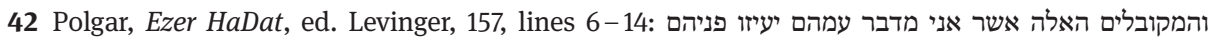

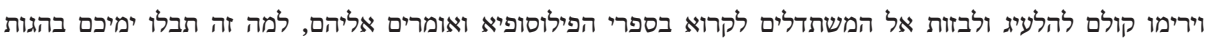

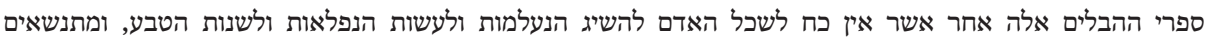

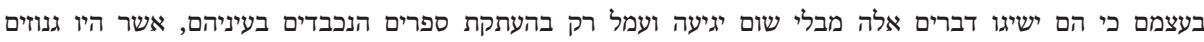

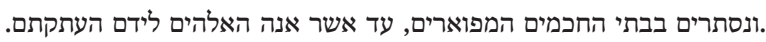

43 Moses de Leon, Sefer Mishkan ha-'Edut, ed. Avishai Bar Asher (Los Angeles: Cherub Press, 2013), 118-119; English translation by Gershom Scholem, Major Trends in Jewish Mysticism (New York: Schocken Books, 1961), 201-202; cf. Boaz Huss, The Zohar: Reception and Impact (Oxford and Portland, OR: The Littman Library of Jewish Civilization, 2016), 42. 
view, magicians-as well as astrologers-believe only in a concept of causality that is entirely erroneous. ${ }^{44}$ In continuing the passage quoted, he tells the following story:

And a man who is acknowledged among our masses for (his) knowledge of Kabbalah and (his) performance of miracles, whose name is Maestre Marcus, told me that in his youth his only activity was seeking for wisdom. And he heard people saying that in a land far away from the islands of Ashkenaz (there lived) a very wise man, and he sought him out. And he went and travelled until he reached him in his land. And he dwelt with him for many days, he worked in his house and served him. When this man saw his diligence and the swiftness of his service, his work was highly esteemed in his eyes, he greatly honoured him and provided him with hospitality. He only avoided teaching him anything, lest he learn (it) and escape from him and return to his land. When he had been there a long time [Genesis 26:8], he was concerned that he was (overly) delayed and detained there, and he was sorry for him. ${ }^{45}$

Polqar claims that a certain man called Maestre Marcus told him how he had received esoteric or magical knowledge in his youth. The peculiar name 'Marcus' is also mentioned in other sources in the context of magical techniques and practices, as well as their transmissions. Thus, in the collection of magical recipes in Ms Bibliothèque de Genève, Comites Latentes 145, Rabbi Elijah Menahem ben Moses of London (c. $1220-1284$ ) is connected to a certain Marcus. ${ }^{46}$ But if this Marcus is the same in both accounts, then the 'very wise man' could probably be identified as Rabbi Elijah of London. Rabbi Elijah is indeed known for his use of divine names for protective purposes and for transmitting magical adjurations. ${ }^{47}$ In line with Rabbi Elijah and his relation to Marcus, the obscure 'islands of Ashkenaz' mentioned in Polqar's text quoted above may quite probably be identified as England. Already in the third chapter of his Ezer ha-Dat, Polqar mentions Ashkenaz-together with France-as places where magic dealing with the names of angels and demons is quite popular among the Jews. ${ }^{48}$ However, it is not entirely clear whether Polqar's Marcus is a fictitious or historical character and whether Polqar's account describes a real personal encounter with him..$^{49}$ Obviously, it is not quite plausible that Marcus had in fact told the story of his acquisition of esoteric knowledge to Polqar in such a self-effacing

44 Cf. the fourth chapter in ibidem, 159-161.

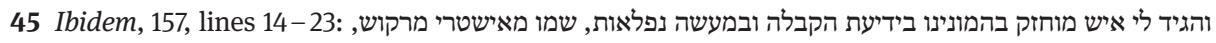

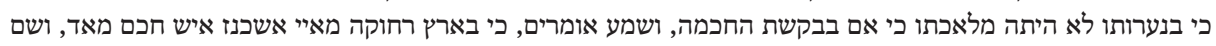

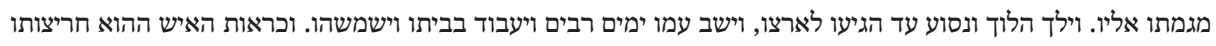

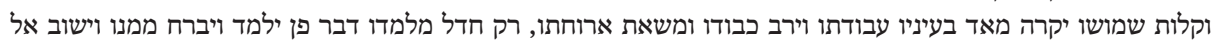

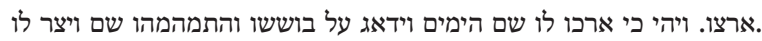

46 Ms Bibliothèque de Genève, Comites Latentes 145 (formerly Ms Sassoon 290), pp. 379-381.

47 Cf. Ephraim Kanarfogel, “Peering through the Lattices”: Mystical, Magical, and Pietistic Dimensions in the Tosafist Period (Detroit: Wayne State University Press, 2000), 232-233.

48 See Polgar, Ezer HaDat, ed. Levinger, 115.

49 On Marcus and Rabbi Elijah of London, including Polqar's account, cf. Amos Goldreich, Automatic Writing in Zoharic Literature and Modernism [in Hebrew] (Los Angeles: Cherub Press, 2010), 289298. 
way. Moreover, the Latin name Marcus sounds more Christian than Jewish. It is most likely that Polqar wished to indicate some Christian influence on this Jew or that he was a former Jew who had converted to Christianity, which is quite fitting regarding his adversary Abner, who called himself Alfonso of Valladolid.

A crucial point mentioned above is that the wise man 'avoided teaching him anything.' Thus from the outset, Maestre Marcus was obviously not a dignified student deserving of at least some of his master's knowledge. His not being worthy of this acquisition will become clear as the story continues:

And he said to himself, 'Since the man is not interested in teaching me, I will therefore turn aside
[Exodus 3:3] if I can take a look in his book and see it, then I will cast my eye on it and copy it.'
And night fell, and he peered into the innermost part of his chamber and, behold, the man was
reclining on his bed, reading in a respected and fine ${ }^{50}$ book. And when fatigue weighed heavily
upon him and sleep overtook him, he placed the book under his head and fell asleep. And when
he [i.e. Maestre Marcus] saw that he was deeply asleep, he came into the chamber and stealthily
placed his hand under his head and stole the book, and then he hastened to the ink and parch-
ment to write it out. And when the sun rose, behold, he had finished copying it, and then he
returned it to the place where it was taken from. ${ }^{.1}$

It is explicit here that Maestre Marcus planned to steal the book for a short period and to copy it while its owner was asleep. This was obviously the only way for him to obtain the secrets that his master had chosen to withhold from him. The placing of a secret book under the head of someone who is asleep probably alludes to the magical practice of a dream request (she'elat halom in Hebrew).$^{52}$ Therefore, in one magical fragment from the Cairo Genizah destined for this purpose, the following instruction is preserved: 'Write the entire issue and place it under your head. ${ }^{53}$ Here, it is clear from the context that 'entire issue' means divine names. And in fact, the secret book under the head contains divine names, as mentioned in the continuation of

50 The Hebrew na'eh should probably be corrected to nora, 'awesome.'

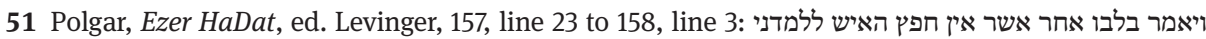

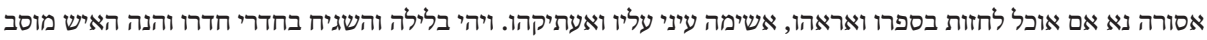

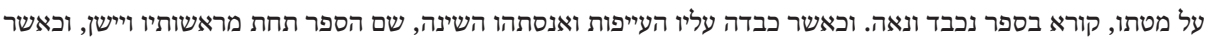

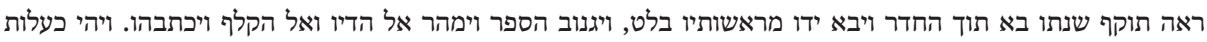

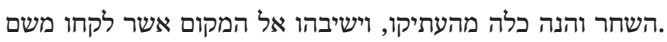

52 On dream requests in medieval Jewish magic, cf., e.g., Trachtenberg, Jewish Magic and Superstition, 241-243; Moshe Idel, “On Še’elat Halom in Hasidei Aškenaz: Sources and Influences,” Materia Giudaica 10 (2005): 99-109.

53 See the Cairo Genizah fragment, Pennsylvania University H457, fol. 1a/10 (unpublished, my translation). The same magical practice can be found in another Genizah fragment concerning the recovery of lost property, cf. CUL T.-S. K 1.96, fol. 2a/12-13, in Magische Texte aus der Kairoer Geniza, vol. 3, eds. Peter Schäfer and Shaul Shaked (Tübingen: Mohr Siebeck, 1999): 369 (No. 84). On this fragment and the placing of the adjuration text under one's head, see Yuval Harari, "Metatron and the Treasure of Gold: Notes on a Dream Inquiry Text from the Cairo Genizah," in Continuity and Innovation in the Magical Tradition, eds. Gideon Bohak, Yuval Harari, and Shaul Shaked (Leiden and Boston: Brill, 2011): 307-308. 
Polqar's story. It is striking that in one of the magical adjurations transmitted by Rabbi Elijah of London, a dream request is also intended. ${ }^{54}$ However, the placing of the book under the head can also simply serve to protect it from thieves, even though-as we learn from Polqar's story-this precaution against theft was somewhat unsuccessful. The concluding part of the story of Maestre Marcus reads as follows:

And when he saw that God had caused his way to succeed, and that he had achieved his desire and yearning, he set out for his land, which was a distance of four months away. But the distance was shortened for him by the power of the adjuration of one of the (divine) names which were written in this book. And he came to his home before a third of the day (was over). Beliefs in such stories of foolishness and all types of nonsense are, on account of our sins, very prevalent among many of the people from the dignities of our nation. ${ }^{55}$

Here, a well-known magical technique is mentioned, the so-called 'shortening of the path' or 'path jumping' (qefișat ha-derekh in Hebrew). The goal of this technique is a miraculous journey between two distant places in a short time. ${ }^{56}$ Polqar describes Maestre Marcus' return to his homeland using the technical terminology established in Jewish magic. The use of magical names in an adjuration for this purpose is well attested in medieval Jewish magic. ${ }^{57}$ The details in the story of Maestre Marcus that Polqar presents clearly show his familiarity with Jewish magical traditions, their features, and their technical language. In any case, it is decisive that Polqar does not provide the reader either with a description of the magical practice itself, including an adjuration, or with any mention of the effective name(s) of God. ${ }^{58}$ Thus, the continuous dissemination of the content and essence of magic is not supported, at least by Polqar. Instead, he chooses another way of dealing with the challenge of magical beliefs and practices performed by Jews. In fact, those who execute magical practices

54 Cf. Kanarfogel, Peering through the Lattices, 232.

55 Polgar, Ezer HaDat, ed. Levinger, 158, lines 3-9: ובראותו כי הצליח האל את דרכו, והשיג תאותו וחשקו,

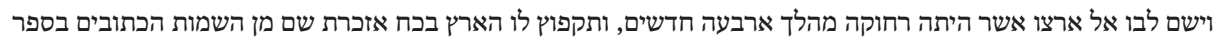

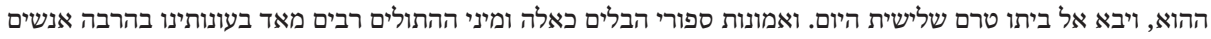
מנכבדי אומתינו.

56 Cf. Mark Verman and Shulamit H. Adler, "Path Jumping in the Jewish Magical Tradition," Jewish Studies Quarterly 1 (1993/94): 131-148; Gedalyah Nigal, Magic, Mysticism and Hasidism: The Supernatural in Jewish Thought (Northvale, NJ: Jason Aronson, 1994), 33-49.

57 Cf., e.g., the magical fragments stemming from the Cairo Genizah JTSL ENA 2871, fol. 7b/7, in Magische Texte aus der Kairoer Geniza, vol. 2, eds. Peter Schäfer and Shaul Shaked (Tübingen: Mohr Siebeck, 1997): 127 (No. 28); CUL T.-S. K 1.115, fol. 1b/9-12, in ibidem, 155 (No. 31); CUL T.-S. AS 143.171, fol. 2b/1-2, in Magische Texte aus der Kairoer Geniza, vol. 3, eds. Peter Schäfer and Shaul Shaked (Tübingen: Mohr Siebeck, 1999): 137 (No. 68).

58 In the last dialogue of the second chapter, the traditionalist mentions the divine names of fortytwo and seventy-two letters among the secrets he has acquired; see Polgar, Ezer HaDat, ed. Levinger, 86. On these names, see Trachtenberg, Jewish Magic and Superstition, 94-97. In the section on magicians also included in the fourth chapter, Polqar actually describes two examples of magic-a love spell and a spell for winning games of dice. However, in both cases, neither an incantation nor any magical name is mentioned; see Polgar, Ezer HaDat, ed. Levinger, 160-161. 
do not necessarily claim to have theoretical knowledge (scientia) concerning the reasons for the efficacy of magic, but usually the practitioner only has practical skills (ars) for performing a magical act. As epistemological scepticism would be directed against a knowledge claim but not against practical skills, Polqar chose another sceptical element in his polemic. Usually, the well-known topos of 'stolen wisdom' or 'theft of wisdom' deals with knowledge transfer between different nations, such as the Jews and the Greeks. ${ }^{59}$ Here, Polqar uses this topos in a slightly different way to deconstruct the self-conception and self-image of Jewish kabbalists. For the purpose of his argument, Polqar does not doubt the quality of wisdom with regard to kabbalistic claims, but rather the legitimation of their ownership of this wisdom. Therefore, his purpose is to delegitimise his opponents' authority and reliability by using stories and experiences acknowledged by the kabbalists. ${ }^{60}$ The crucial point of his method is to avoid answering the question regarding the kabbalists' claims that Kabbalah is knowledge or indeed even wisdom.

At the end of this passage, Polqar once again presents his epistemological premises on the possibility of knowledge. At the same moment, he aims to define 'true tradition' as opposed to the self-image of Kabbalah:

\begin{abstract}
And these ignorants ${ }^{61}$ do not know, nor do they understand, that we possess no faculty more honoured and more elevated than the rational faculty, through which we can attain the hidden (matters). And the only way to attain this faculty is through seeking out the middle term and the construction of a demonstration. To be sure, the apprehension of the prophet is not (attained) through combining the premises and seeking out the demonstration, but through a way more honoured and elevated than them. However, the apprehension of the hearers of his words and (what) they receive [meqabbelim] from him cannot be compared to it [i.e. the prophet's apprehension] in any way. And the topic of the true tradition [qabbalah] and the measure of the apprehension of those who receive [meqabbelim] it from the mouth of the prophet or from one who receives [meqabbel] (it) from another who received [mequbbal] it is written in the book Musar ha-Banim ['The Instruction of the Sons'] (written) by me. ${ }^{62}$
\end{abstract}

For a philosopher such as Polqar, men are able to attain hidden things with the help of the rational faculty, which is only possible by following the principles of Aristotelian syllogisms. The prophet's way of attaining hidden matters is not only different to this philosophical approach, but also 'more honoured and elevated.' Nevertheless,

59 Cf. Abraham Melamed, The Myth of the Jewish Origins of Science and Philosophy [in Hebrew] (Jerusalem: Magnes Press, 2010), 178-219 and now Giuseppe Veltri, Alienated Wisdom: Enquiry into Jewish Philosophy and Scepticism (Berlin and Boston: De Gruyter, 2018), 21-42.

60 On delegitimation as a sceptical strategy, cf. Rebiger, “Sceptical Strategies in Simone Luzzatto’s Presentation of the Kabbalists in his Discorso," 64-66.

61 Literally 'those who are lacking understanding,' here meaning the kabbalists.

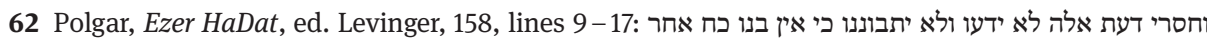

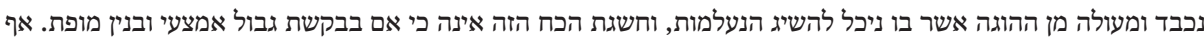

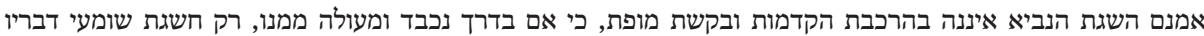

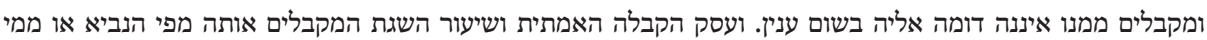

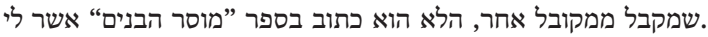


neither the receiver of the prophetic tradition nor the tradition itself share the same quality of apprehension. The assumption that the prophet and the receivers of his tradition are epistemologically equal is considered the kabbalists' main mistake. Unfortunately, the elaboration of the true Kabbalah in Polqar's Musar ha-Banim (mentioned above) is unknown as the book did not survive.

\section{Conclusion}

The Hebrew word 'Kabbalah' literally means 'tradition.' Polqar's goal in his attack on the kabbalists is to undermine the acceptance of kabbalistic opinions among his contemporaries by implementing a sceptical element which argues that Kabbalah is not a real tradition. In doing so, he attempts to undermine the reliability of the claim that the Kabbalah possesses a tradition that dates back to the time of the ancient prophets. Polqar's main sceptical elements are the focus on doubts about the textual accuracy of kabbalistic sources and the question of whether the kabbalists acquired their knowledge honestly. Thus, Polqar deconstructs Kabbalah's self-presentation as an ancient tradition continuously transmitted since antiquity on the one hand and the legitimacy of kabbalistic authorities on the other. In both examples, Polqar does not deal with the specific content of kabbalistic claims, but with the general framework of tradition and its reception of them, thus emphasising the literal meaning of Kabbalah. The qal wa-homer conclusion or argumentum a fortiori used in the first example concerning the deficiency of kabbalistic texts is not convincing when kabbalists claim that they copied and checked kabbalistic texts in the same way as the Holy Scriptures. The weakness of Polqar's argument in his second example implementing the story of Maestre Marcus is found in the inductive reasoning: even if one accepts the veracity of Polqar's personal story of Maestre Marcus, it nonetheless provides only one example of the topos of stolen wisdom but cannot as such guarantee its general validity for all kabbalistic texts. Therefore, I would not call Polqar's approach a fully-fledged sceptical strategy, but rather one which only contains elements of scepticism which, in turn, are embedded in a dogmatic stance. 
